\title{
PENGUKURAN TINGKAT KEBERGUNAAN SISTEM INFORMASI ANALISIS JABATAN DAN BEBAN KERJA MENGGUNAKAN TECHNOLOGY ACCEPTANCE MODEL
}

\author{
${ }^{1 *}$ Krismadinata, ${ }^{2}$ Wulan Juswita Sari, ${ }^{3}$ Ganefri, ${ }^{4}$ Unung Verawardina \\ ${ }^{1,3}$ Jurusan Teknik Elektro, Universitas Negeri Padang Jalan. Prof. Dr. Hamka Air Tawar Padang \\ ${ }^{2}$ Kantor Pemerintah Kota Payakumbuh, Jalan Jend. Sudirman No. 17, Kota Payakumbuh \\ ${ }^{4}$ Program Studi Pendidikan Teknologi Informasi dan Komputer, IKIP PGRI Pontianak \\ Email: krisma@ft.unp.ac.id
}

(Diterima: 8 Januari 2020, direvisi: 7 Mei 2020, disetujui: 1 Juli 2020)

\begin{abstract}
The existence of information and communication technology (ICT) in an organization is expected to increase the efficiency and effectiveness of the organization. This condition is sometimes far from what is expected and instead slows organizational activities such as the ability to use computer-based information systems that are still low, and user experience is still small so that it affects the acceptance of an information system. Job Analysis and Workload Analysis Information System (SINJAB) is designed to provide the results of job analysis and workload analysis from a Central / Regional agency for the implementation of institutional, staffing, management and supervision arrangements to the competency-based apparatus and performance. This article discusses the process of measuring the usefulness of the acceptance of the SINJAB. The method used is the Technology Acceptance Model (TAM). The parameters used to measure variable factors such as experience, selfconfidence, perceived usefulness, and perceived ease of use on the acceptance of the SINJAB. The object of the study was conducted at the Government of the City of Payakumbuh, West Sumatra. The findings state all the factors of experience, self-confidence, perceived usefulness, and perceived ease affect the SINJAB.
\end{abstract}

Keywords:

Keywords: ICT, SINJAB ,technology acceptance model

\begin{abstract}
ABSTRAK
Keberadaan teknologi informasi dan komunikasi (TIK) dalam suatu organisasi diharapkan dapat meningkat efisien dan efektifitas organisasi. Kondisi ini kadang-kadang jauh dari apa yang diharapkan dan malah memperlambat aktifitas organisasi seperti kemampuan menggunakan sistem informasi berbasis komputer yang masih rendah, dan pengalaman pengguna masih sedikit sehingga mempengaruhi penerimaan suatu sistem informasi. Sistem Informasi Analisis Jabatan dan Analisis Beban Kerja (SINJAB) dirancang untuk menyediakan hasil analisis jabatan dan analisis beban kerja dari suatu instansi Pusat/Daerah untuk pelaksanaan penataan kelembagaan, kepegawaian, ketatalaksanaan dan pengawasan kepada aparatur yang berbasis kompetensi dan kinerja. Artikel ini membahas tentang proses pengukuran tingkat kebergunaan penerimaan SINJAB. Metode yang digunakan Technology Acceptance Model (TAM). Parameter yang digunakan untuk mengukur faktor variabel seperti pengalaman, keyakinan diri, persepsi manfaat, dan persepsi kemudahan penggunaan terhadap penerimaan SINJAB. Objek kajian dilakukan pada Pemerintah Kota Payakumbuh Sumatera Barat. Hasil temuan menyatakan semua faktor pengalaman, keyakinan diri, persepsi manfaat, dan persepsi kemudahan berpengaruh terhadap SINJAB.
\end{abstract}

Kata Kunci: TIK , SINJAB , technology acceptance model 


\section{PENDAHULUAN}

Perkembangan TIK semakin dinamis sejalan dengan paradigma era revolusi industri 4,0. sehingga mendapat perhatian besar oleh masyarakat untuk menggunakan teknologi di segala bidang. Perkembangan tersebut membawa transformasi teknologi di lingkungan organisasi seperti pergeseran dalam cara bekerja, pertukaran informasi, sarana sosial, proses bisnis dan lainnya. Melalui teknologi memberi peluang bagi lingkungan organisasi untuk melakukan pekerjaan yang efisien sehingga memungkinkan memanfaatkan penggunaan teknologi dengan menggunakan aplikasi perkantoran [1]. Penggunaan teknologi di lingkungan organisasi salah satunya melalui sistem informasi yakni melalui SINJAB yang merupakan pendukung program kegiatan mengenai rincian tugas dan syarat pada suatu jabatan, serta memberikan kemudahan untuk melakukan perhitungan beban kerja pada Satuan Kerja Perangkat Daerah (SKPD) dan setiap jabatan [2] Pelaksanaan SINJAB pada dasarnya bertujuan supaya terpenuhinya efektivitas, efisiensi dan profesionalisme karyawan di organisasinya. Akan tetapi untuk penerimaan sistem tersebut perlu adanya pengukuran kebergunaan pada penerimaan sistem untuk melihat sejauhmana sistem sesuai kebutuhan. Metode yang dapat mengukur sistem informasi meliputi Theory of Reason Action (TRA), End-User Computing Satisfaction (EUCS), Task Technology Fit (TTF) serta Technology Acceptance Model (TAM) [3].

Pada metode TAM dapat mengukur penerimaan teknologi dari segi perilaku pengguna, TAM lebih baik untuk menjelaskan keinginan pengguna menerima teknologi dibandingkan dengan TRA [4]. Sebab pada TRA mengukur sistem informasi hanya ditingkat pengaruh sosial (norma subjektif) [5]. Sedangkan TTF bertugas menginputkan performance user pada sistem [6] Metode TTF lebih memposisikan TIK hanya digunakan apabila ketersediaan fungsi dan manfaat dalam mendukung aktivitas user [7]. Serta EUCS untuk melakukan evaluasi pada sistem informasi [8] Pada metode EUCS lebih menekankan evaluasi kepuasan pengguna akhir dari sistem, hasilnya menunjukkan tidak banyak berpengaruh pada penerimaan sistem informasi [9]. Apabila dibandingkan dengan ketiga metode tersebut, maka metode TAM diangap lebih tepat mengukur kebergunaan SINJAB dari pada metode lainnya, alasannya karena TAM memiliki kejelasan dan sederhana dalam penerimaan teknologi serta mempertimbangkan perilaku penggunanya, fokus utamanya pada variabel kegunaan dan kemanfaatan.

Pada penelitian sebelumnya oleh [10] tentang penerimaan pengguna sistem informasi pada variabel persepsi penerimaan kemudahan, pemanfaatan dan prilaku saja yang diukur melalaui TAM. Namun pada penelitian ini diukurnya sistem informasi pada variabel pengalaman, keyakinan diri, persepsi manfaat, dan persepsi kemudahan penggunaan. Secara luas TAM diterapkan dan diuji secara empiris [4]. TAM menjadi salah satu penelitian dominan di Indonesia mengenai disiplin manajemen teknologi [10]. Dengan demikian melalui teknologi TAM dapat membantu pencapaian optimal mencapai sasaran pekerjaan yang efektif. Ketika pengguna menggunakan sistem dapat dipengaruhi yang meliputi usefulness mengenai pengguna yang beragapan dapat meningkatkan kinerja, ease of use dimana pengguna yakin akan kemudahan sistem sehingga dapat mengatasi kesulitan dalam pekerjaan, pengalaman dalam menggunakan sistem yang memberikan dampak yang baik, dan penerimaan sistem yang dapat diterima oleh pengguna.

Pemerintah Kota Payakumbuh memanfaatkan teknologi sistem informasi dalam pencapaian tujuan organisasi melalui penggunaan SINJAB. Model penerimaan teknologi untuk memprediksi penerimaan dapat melalui persepsi kemudahan dan manfaat pada pengguna. Hasil temuan [11]menunjukkan bahwa adanya korelasi yang baik antara kegunaan dan penerimaan, sedangkan antara kegunaan dan kemudahan penggunaan tergolong baik, namun hubungan antara kemudahan penggunaan dan penerimaan rendah. Sistem informasi ini diharapkan mempermudah dalam melakukan SINJAB jika dibandingkan dengan pelaksanaan secara manual. Akan tetapi fakta yang terjadi pemanfaatan SINJAB dirasakan belum optimal, penggunaan secara intensif dan update data hanya pada saat awal-awal pelatihan pemakaian SINJAB. Hal ini terlihat dari 31 SKPD yang ada, 16 SKPD $(51,61 \%)$ mengalami perubahan nama SKPD, namun belum terupdate pada SINJAB. Diduga terjadi karena adanya kesulitan oleh operator dalam penggunaan SINJAB, ini muncul dari keyakinan diri terhadap kemampuan menggunakan sistem berbasis komputer yang masih rendah karena tidak terbiasa dengan TIK baru. Pengalaman pengguna masih sedikit dalam menggunakan suatu sistem informasi tertentu yang mempengaruhi penerimaan suatu sistem informasi, hal ini terlihat dari data pelatihan sosialisasi pertama dari 31 SKPD, hanya 13 orang $(41,93 \%)$ yang pernah mengikuti 
pelatihan TIK sebelum berprofesi sebagai operator SINJAB, dan selebihnya baru pertama kali dalam pengguna sistem informasi yang sejenis.

Berdasarkan permasalahan tersebut, perlu dilakukan analisis penerimaan terhadap penerapan sistem informasi. Analisis yang dilakukan untuk memperoleh penerimaan pengguna melalui metode TAM yang telah dimodifikasi. Tujuanya mengkur tingkat kebergunaan pada variabel pengalaman, keyakinan diri, persepsi manfaat, dan persepsi kemudahan penggunaan terhadap penerimaan SINJAB.

\section{TINJAUAN PUSTAKA}

\subsection{Persepsi Penerimaan}

Pada suatu organisasi sistem informasi dapat digunakan untuk mencari informasi, memproses dan menghasilkan informasi sesuai lingkungan organisasi sehingga sistem informasi bisa diterima. Model penerimaan teknologi mengusulkan bahwa persepsi kemudahan serta persepsi manfaat perlu dipertimbangkan untuk penerimaan TIK. Salah satu contoh seperti perangkat komputer yang sering digunakan, dimana penggunaan sistem merupakan indikator penerimaan dari komputer [4]. Melalui TAM juga dapat menganalisis penerimaan seseorang terhadap persepsi nilai hiburan dan daya tarik persentasi [12]. Maka penerimaan sistem informasi pada pengguna dapat dikemas bervariasi sehingga mampu diterima.

\subsection{Technologi Acceptance Model}

TAM diartikan sebagai satu model paling banyak digunakan memaparkan perilaku penerimaan pengguna. Model ini didasarkan pada teori psikologi sosial secara umum dan Theory of Reasoned Action (TRA) pada khususnya [13]. Konstruksi pada TAM meliputi persepsi kegunaan, kemudahan dalam penggunaan, sikap pelaku pengguna aplikasi, dan niat perilaku untuk digunakan. Diantara konstruk, persepsi kegunaan dan kemudahan membentuk keyakinan pengguna akhir pada suatu teknologi dan tujuanya untuk memprediksi sikap terhadap teknologi sehingga dapat memprediksi penerimaannya. [4]. Diagram relasi variable-variabel yang terlibat dalam model TAM dapat dilihat pada Gambar 1.

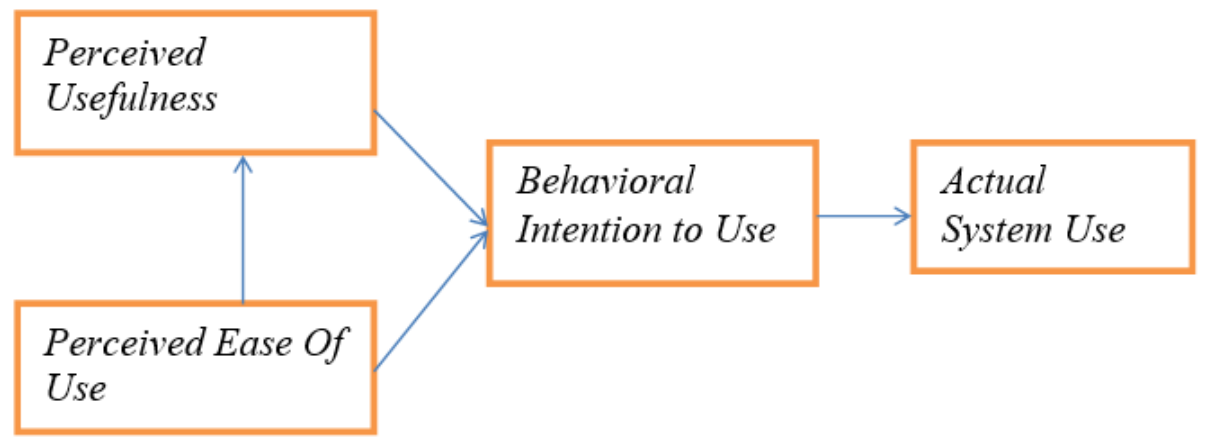

Gambar 1. Technology Acceptance Model (TAM)

\subsection{Persepsi Manfaat}

Persepsi manfaat adalah kepercayaan pengguna terhadap teknologi yang mampu memberikan keringanan pada pekerjaan. Apabila seseorang percaya sistem informasi memiliki manfaat maka pengguna akan menggunakan sistem tersebut [14].

\subsection{Persepsi Kemudahan Pengguna}

Membuat program komputer tentu harus melihat keefisiensi sesuai pengguna. Unsur kemudahan menjadi bahan pertimbangan dalam mengambangkan suatu sistem. Dengan intensitasnya pengguna menggunakan sistem menujukan bahwa adanya kemudahan [15]. Dari sistem yang memberikan kemudahan inilah suatu sistem diangap baik. Tolak ukur kemudahan TIK memuat komputer yang mudah dipahami, mengikuti perintah dari pengguna, mudah dalam meningkatkan keahlian 


\subsection{Pengalaman(Experience)}

Pengalaman seseorang menggunakan perangkat komputer mampu memberikan pengaruh penerimaan melalui kepercayaan dengan adanya kemudahan penggunaan persepsi dan manfaat [16]. Pengalaman didapat baik secara langsung dan tidak langsung, misalnya pengaruh pengalaman terhadap kemahiran penggunaan personal computer.

\subsection{Keyakinan Diri (Self-Efficacy)}

Self efficacy yakni penilaian seseorang mengenai kemampuan dalam capaian kerja.[17] Melalui self efficacy mampu membuat persepsi manfaat [18]. Hasil temuan [19] menunjukan bukti empiris efek positif self-efficacy pada perilaku terhadap penggunaan teknologi, implikasinya penting bagi para praktisi dan manajer untuk mempertimbangkan dengan cermat faktor-faktor yang bisa mempromosikan penggunaan teknologi.

\subsection{SINJAB}

SINJAB merupakan bagian dari unsur manusia dan perangkat pengelolahan informasi yang bertujuan menampilkan informasi seputar jabatan, kebijakan, program, data kepegawaian, feedback organisasi dan lainnya [2]. Sehingga SINJAB ini dapat digunakan sebagai pedoman dalam capaian kinerja dalam suatu organisasi.

SINJAB merupakan suatu aplikasi system informasi yang dibuat dan dapat ditelusuri lewat jaringan (daring). Setiap operator dapat mengakses aplikasi melalu web browser seperti Mozilla Firefox, Opera, Internet Explore, Crome dan browser lainnya, dengan mengakses alamat http://payakumbuhkota.sinjab.info dan login sesuai dengan username dan password SKPD masing-masing pada halaman depan SINJAB Pemerintah Kota Payakumbuh seperti yang terlihat pada Gambar 2.

Sistem informasi SINJAB ini memiliki fitur dan keunggulan yakni (1) memudahkan dalam pengisian data yang terkait dengan analisis jabatan dan analisis beban kerja. (2) Tersedia menu cetak untuk semua kelengkapan analisis jabatan dan analisis beban kerja, baik yang dibutuhkan oleh Badan Kepegawaian Negara maupun oleh Kementerian Dalam Negeri. (3) Memudahkan dalam prose pencarian jabatan dan tugas fungsinya masing-masing. (4) Memudahkan dalam penghitungan beban kerja masing-masing SKPD dan setiap jabatan. (5) Data yang ada dapat dikonversi dalam bentuk file PDF.

Alur sistem analisis jabatan dan analisis beban kerja pada SINJAB Pemerintah Kota Payakumbuh diperlihatkan pada Gambar 3. SINJAB selain efektif dalam memberikan kemudahan dalam proses analisis jabatan juga mempercepat dan meningkatkan akurasi data mengenai beban kerja.

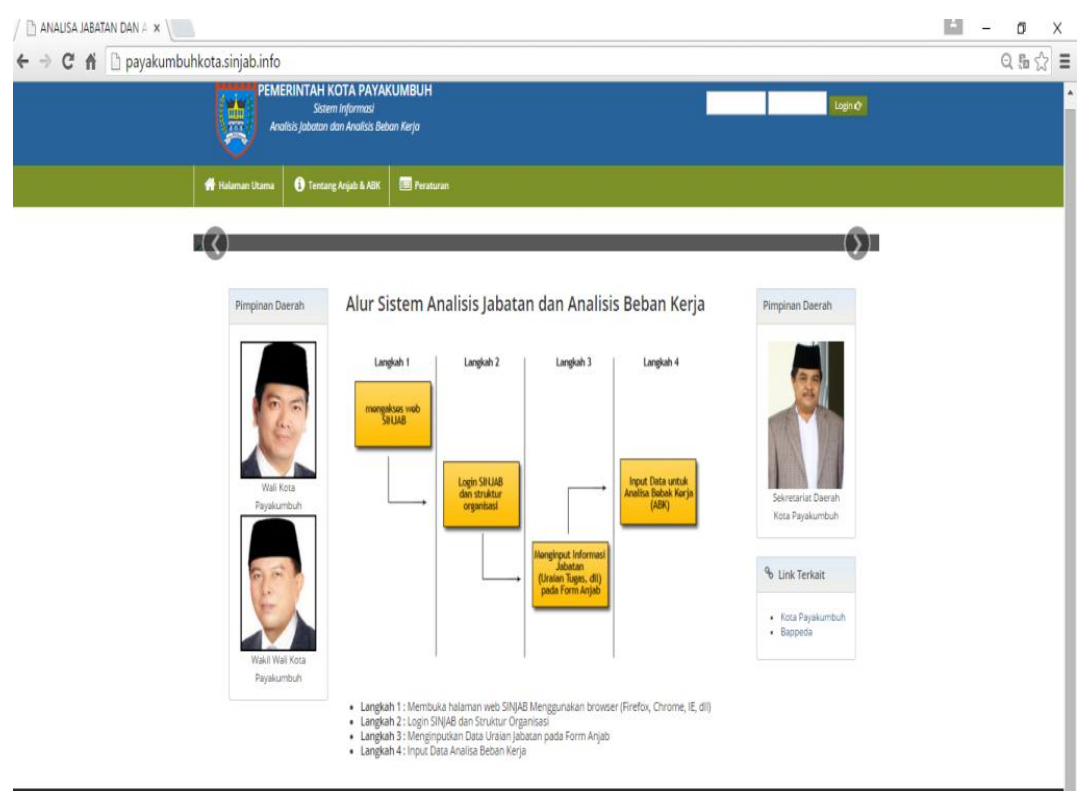

\section{Gambar 2. Halaman Depan SINJAB Pemerintah Kota Payakumbuh}




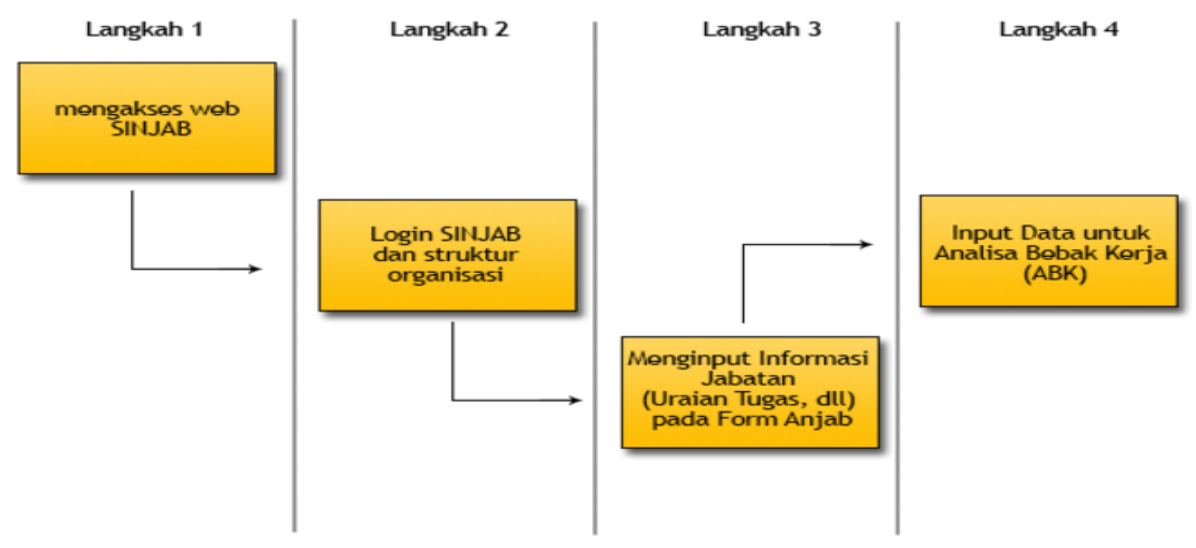

Gambar 3. Alur Sistem Analisis Jabatan Dan Analisis Beban Kerja

\section{METODE PENELITIAN}

Kajian ini memfaatkan kuesioner/angket sebagai alat pengumpulan data yang ditujukan untuk mengetahui penerimaan operator SKPD terhadap SINJAB Pemerintah Kota Payakumbuh. Metodologi yang diterapkan Structural Equation Modelling berbasiskan variance. Untuk melihat hubungan antar variabel, adapun variabel laten eksogen (bebas) yakni pengalaman, keyakinan diri, persepsi manfaat dan persepsi kemudahan dan variabel laten endogen (terikat) yakni Penerimaan SINJAB. Penelitian ini dilakukan kepada seluruh operator SINJAB SKPD Pemerintah Kota Payakumbuh dengan jumlah responden 31 orang, yang didapat melalui teknik sampel jenuh dengan menjadikan keseluruhan populasi sebagai sampel [20]. Instrument yang digunakan yakni kuisioner yang memuat pertanyaanpertanyaan pada variabel penelitian. Analisis data validitas dan realibilitas menggunakan outer model. Pada inner model digunakan memprediksi hubungan pengaruh pada variabel [21].

Secara garis besar, kerangka konseptual dalam kajian yang dilakukan ini digambarkan pada Gambar 4.

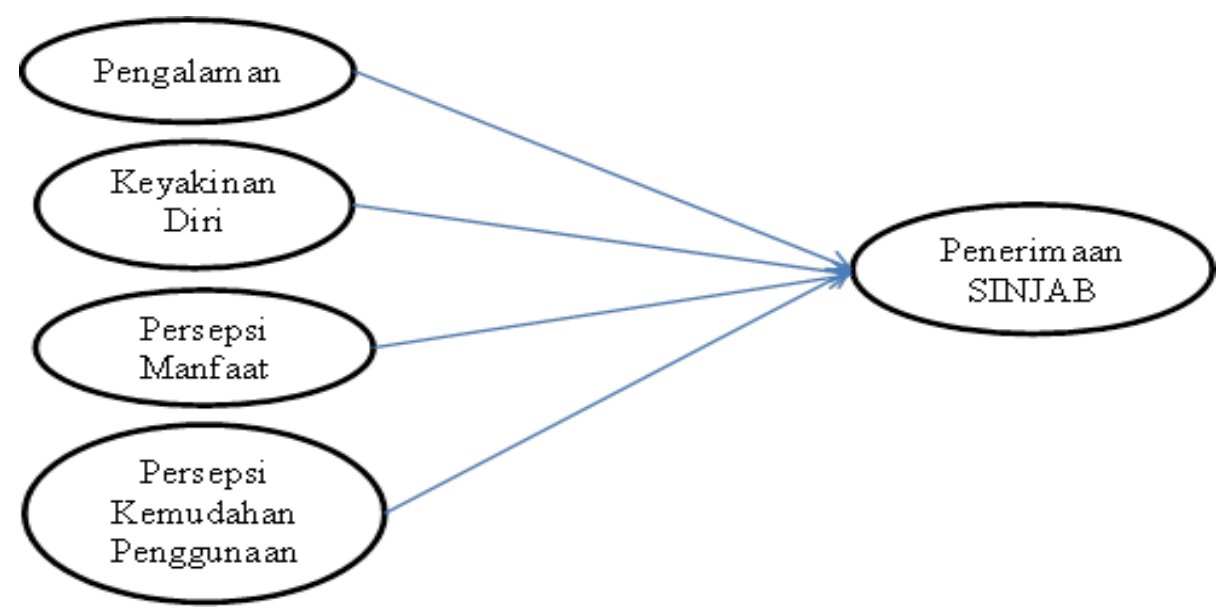

Gambar 4. Kerangka Konseptual

Seperti terlihat pada Gambar 4, dalam penelitian ini diajukan lima konstruk faktor yang mendasari yakni: pengalaman, Keyakinan diri, persepsi manfaat, persepsi kemudahan penggunaan dan penerimaan TIK dalam hal ini SINJAB.

Model konseptual yang diajukan mengadopsi beberapa model TAM dengan menyesuaikan pada konteks penerimaan SINJAB Pemerintah Kota Payakumbuh. Pemilihan konstruk faktor juga disesuaikan dengan permasalahan yang dihadapi dalam penerimaan terhadap SINJAB Pemerintah Kota Payakumbuh.

Hipotesis yang diajukan dalam penelitian ini yakni; (1) Hipotesis 1: pengalaman (experience) dapat berpengaruh signifikan terhadap penerimaan SINJAB Pemerintah Kota 
Payakumbuh. (2) Hipotesis 2: keyakinan diri (self efficacy) dapat berpengaruh signifikan terhadap penerimaan SINJAB. (3) Hipotesis 3: persepsi manfaat yang dirasakan (perceived usefulness) berpengaruh signifikan terhadap penerimaan SINJAB Pemerintah Kota Payakumbuh. (4) Hipotesis 4: persepsi kemudahan penggunaan (perceived ease of use) berpengaruh signifikan terhadap penerimaan SINJAB Pemerintah Kota Payakumbuh.

Variabel-variabel penelitian dikembangkan menjadi indikator-indikator yang diuraikan menjadi butir-butir pertanyaan yang akan dijadikan kuesioner. Jumlah butir pertanyaan pada instrumen ini adalah 46 butir pertanyaan. Kisi-kisi pertanyaan dalam instrumen ini dapat dilihat pada Tabel 1.

\section{HASIL DAN PEMBAHASAN}

Penerimaan penggunaan teknologi didasari adanya niat perilaku seseorang untuk menggunakan sebuah sistem informasi [22]. Menurut [23] niat perilaku cenderung berkorelasi dengan penggunaan aktual. TAM merupakan suatu model yang memaparkan perilaku terhadap penerimaan TI oleh karena itu pada peneltian ini merjuka kepada penggunaan model TAM. Penelitian dilakukan terhadap operator SINJAB Pemerintah Kota Payakumbuh, yang berjumlah 31 orang, dalam melakukan analisis data menggunakan PLS. Hasil temuan ini tergambarkan pada diagram jalur model konseptual terlihat pada Gambar 5.

Untuk evaluasi model pengukuran ini maka dilakukanya tahap pertama melalui analisis data tentang pengaruh masing-masing indikator-indikator terhadap variabel-variabelnya melalui pengujian validitas. Pengujian validitas konvergen melalui factor loading, Communality, dan Average Variance Extracted (AVE) dari masing-masing variabel laten. Variabel indikator dinyatakan valid jika memenuhi semua rule of thumbs pada Tabel 1. Setelah di running, hasil pengolahan menunjukkan nilai factor loading, AVE dan Communality semua variabel, dan terdapat satu indikator tidak valid yaitu EX1 untuk variabel laten pengalaman. Untuk variabel dinyatakan tidak valid maka variabel tidak dimasukan ke model dan setelah direvisi didapat hasil seperti Gambar 6.

Tabel 1. Indikator-Indikator Variabel dan Kisi-kisi Pertanyaan

\begin{tabular}{|c|c|c|}
\hline Variabel & Indikator & Item Pertanyaan \\
\hline $\begin{array}{l}\text { Pengalaman } \\
\text { (Experience) }\end{array}$ & $\begin{array}{l}\text { 1. Pengalaman penggunaan Sistem } \\
\text { Informasi } \\
\text { 2. Lama Penggunaan }\end{array}$ & $\begin{array}{l}\text { EX1,EX2,EX3, } \\
\text { EX4 } \\
\text { EX5,EX6,EX7 }\end{array}$ \\
\hline $\begin{array}{l}\text { Keyakinan Diri } \\
\text { (Self Efficacy) }\end{array}$ & $\begin{array}{ll}\text { 1. } & \text { Keyakinan mampu } \\
\text { menggunakan SINJAB } \\
\text { 2. } \\
\text { Keyakinan mahir menggunakan } \\
\text { SINJAB }\end{array}$ & $\begin{array}{l}\text { SE1, SE2, SE3, SE4, SE5, } \\
\text { SE6, SE7 } \\
\text { SE8, SE9 }\end{array}$ \\
\hline $\begin{array}{l}\text { Persepsi } \\
\text { Manfaat } \\
\text { (Perceived } \\
\text { Usefulness) }\end{array}$ & $\begin{array}{l}\text { 1. } \text { Pekerjaan lebih mudah } \\
\text { 2. } \text { Bermanfaat } \\
\text { 3. } \\
\text { 4. } \\
\text { 4enambah produktivitas } \\
\end{array}$ & $\begin{array}{l}\text { PU1, PU2 } \\
\text { PU3, PU4, PU5 } \\
\text { PU6, PU7, PU8 } \\
\text { PU9, PU10, PU11 }\end{array}$ \\
\hline $\begin{array}{l}\text { Persepsi } \\
\text { Kemudahan } \\
\text { Penggunaan } \\
\text { (Perveived Ease } \\
\text { of Use) }\end{array}$ & $\begin{array}{ll}\text { 1. } & \text { Mudah dipelajari } \\
\text { 2. } & \text { Mudah digunakan } \\
\text { 3. } & \text { Fleksibel }\end{array}$ & $\begin{array}{l}\text { PEU1, PEU2, PEU3, PEU4, } \\
\text { PEU5 } \\
\text { PEU6, PEU7, PEU8, PEU9 } \\
\text { PEU10, PEU11 }\end{array}$ \\
\hline $\begin{array}{l}\text { Penerimaan } \\
\text { SINJAB }(I T \\
\text { Acceptance })\end{array}$ & $\begin{array}{ll}\text { 1. } & \text { Frekuensi penggunaan } \\
\text { 2. } & \text { Penilaian Kepuasan terhadap } \\
\text { SINJAB } \\
\text { 3. Pemanfaatan SINJAB dalam } \\
\text { mendukung aktivitas organisasi }\end{array}$ & $\begin{array}{l}\text { ACC1, ACC2, ACC3, } \\
\text { ACC4, ACC5, ACC6 } \\
\text { ACC7, ACC8 }\end{array}$ \\
\hline
\end{tabular}


Tabel 2. Hasil Rule of Thumbs

\begin{tabular}{cll}
\hline Validitas & \multicolumn{1}{c}{ Keterangan } & \multicolumn{1}{c}{ Rule of thumbs } \\
\hline \multirow{3}{*}{ Konvergen } & Faktor Loading & $>0,5$ \\
& AVE & $>0,5$ \\
& Communality & $>0,5$ \\
Diskriminan & Cross Loading & $>0,7$ \\
& Cronbach's Alpha & $>0,7$ (konformasi) \\
& Reliabilitas & $>0,6$ (exploratory) \\
& Composite & $>0,7$ (konfirmasi) \\
& Reliability & $>0,6$ (exploratory) \\
\hline
\end{tabular}

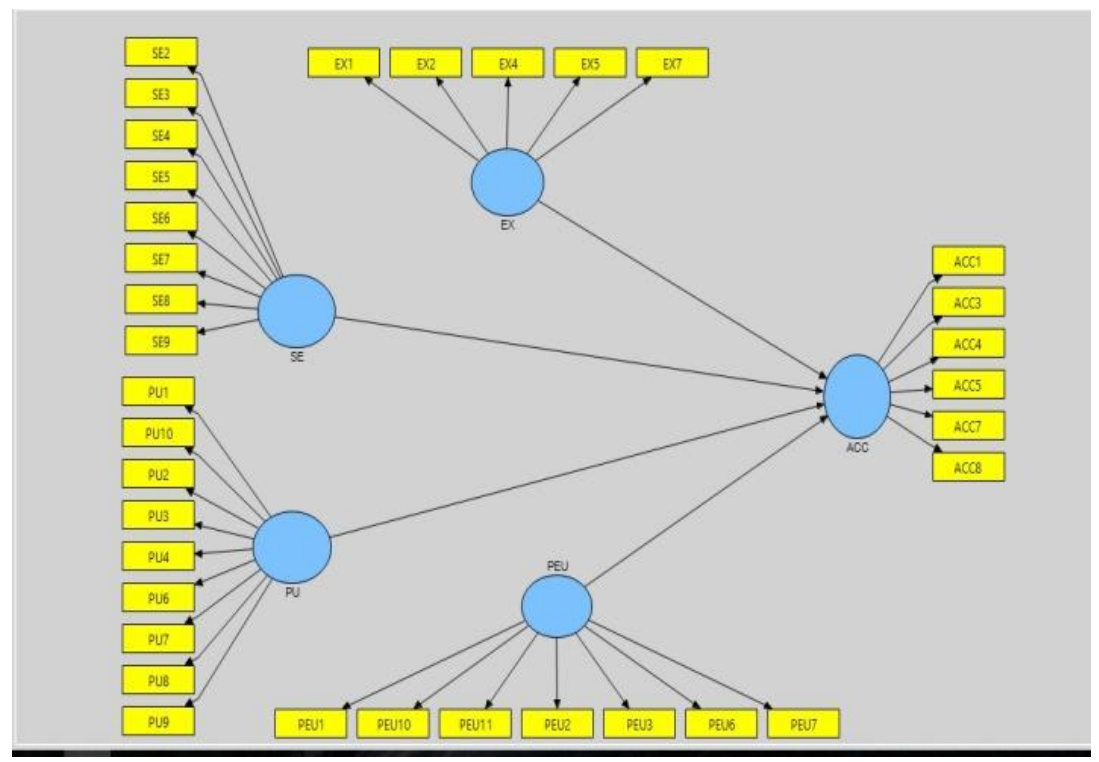

Gambar 5. Diagram Jalur Model Konseptual

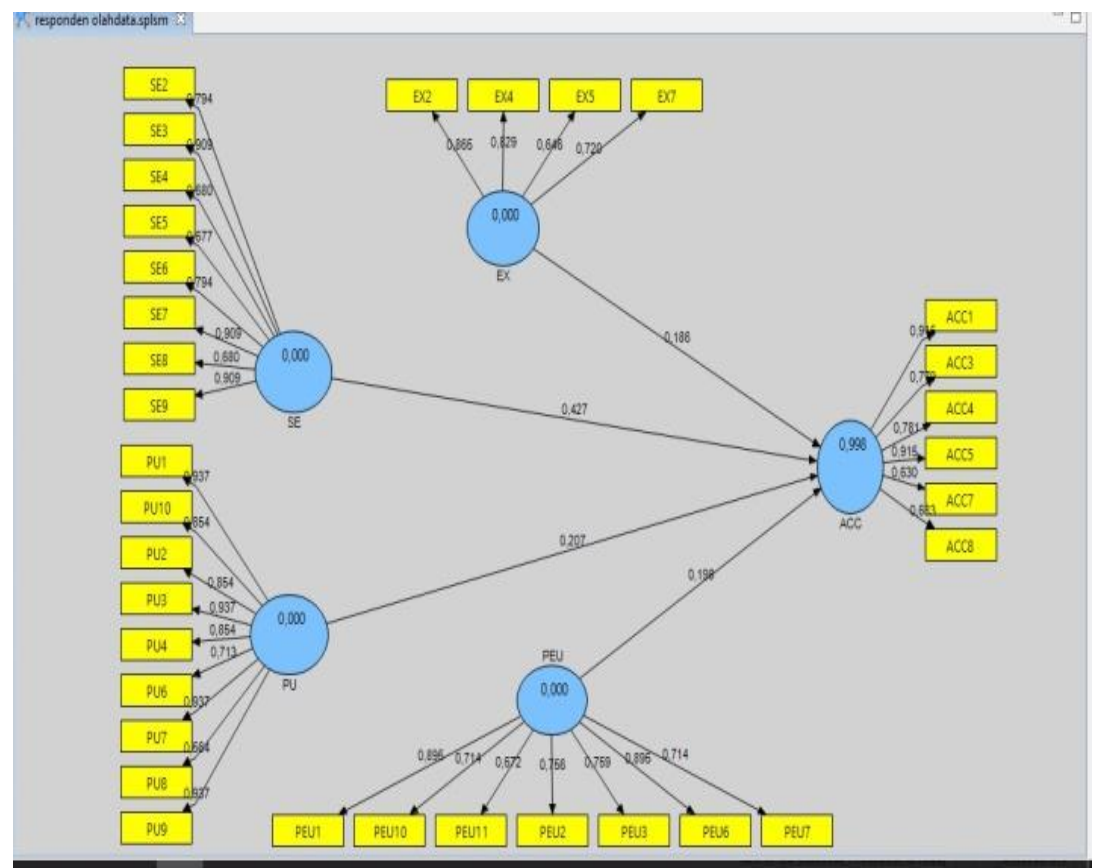

\section{Gambar 6. Diagram Jalur Model Hasil Running Model Pls Setelah Validasi}

Pada Gambar 6 terlihat bahwa nilai factor loading untuk semua indikator $>0,5$ yang berarti keseluruhan indikator pada variabel valid. Dengan demikian tiap variabel yang terdapat pada 
kuesioner digunakan. Kemudian untuk variabel indikator yang tidak valid tersebut dikeluarkan, selain nilai factor loadingnya, nilai AVE dan nilai Communality juga menunjukkan bahwa semua variabel laten sudah valid. Berikut disajikan di Tabel 2:

\begin{tabular}{lcl}
\multicolumn{3}{c}{ Tabel 2. AVE dan Communality Setelah Validasi } \\
\hline \multicolumn{1}{c}{ Variabel } & Nilai AVE & Nilai Communality \\
\hline EX & 0,592905 & 0,592905 \\
SE & 0,640465 & 0,603023 \\
PU & 0,725229 & 0,725229 \\
PEU & 0,603023 & 0,603023 \\
ACC & 0,625637 & 0,625637 \\
\hline
\end{tabular}

Berdasarkan tabel 2 tersebut nilai yang tidak valid maka akan dilakukanya revisi. Pengujian outer model berikutnya adalah pengujian reliabilitas. Pengujian reliabilitas dievaluasi dengan rule of thumbs [21]. Evaluasi ini dilakukan menggunakan yang valid. Hasil pengujian disajikan di Tabel 3:

Tabel 3. Evaluasi

\begin{tabular}{lccc}
\hline Variabel & $\begin{array}{l}\text { Composite } \\
\text { Reliability }\end{array}$ & $\begin{array}{l}\text { Cronbach's } \\
\text { Alpha }\end{array}$ & Keterangan \\
\hline EX & 0,851878 & 0,771215 & Reliability \\
SE & 0,933462 & 0,917353 & Reliability \\
PU & 0,959914 & 0,949412 & Reliability \\
PEU & 0,913152 & 0,888514 & Reliability \\
ACC & 0,907794 & 0,875494 & Reliability \\
\hline
\end{tabular}

Dari tabel 3. terlihat bahwa hasil evaluasi sudah memenuhi rule of thumbs yaitu menunjukkan nilai 0,6. maka variabel layak berada dalam model. Berikutnya dilakukan analisis inner model yang bertujuan mencari hubungan tiap konstruk laten, yakni hubungan signifikansi jalur melalui pengujian hipotesis dan evaluasi goodness of fit untuk kelayakan model. Hasil hubungan signifikansi jalur di Tabel 4:

Tabel 4. Koefisien Jalur

\begin{tabular}{lll}
\hline \multicolumn{1}{c}{ Jalur } & \multicolumn{1}{c}{ Sample } & \multicolumn{1}{c}{ Nilai T } \\
\hline EX -> ACC & 0,186482 & 5,227698 \\
SE -> ACC & 0,427147 & 5,938583 \\
PU -> ACC & 0,206595 & 4,536253 \\
PEU -> ACC & 0,197737 & 2,189381 \\
\hline
\end{tabular}

Terlihat pada tabel 4 bahwa semua jalur memiliki hubungan yang signifikan pada $\alpha=5 \%$, yaitu $\mathrm{t}_{\text {statistik }}>1$,96. Pada jalur variabel pengalaman ke variabel penerimaan (EX->ACC) didapatkan nilai $\mathrm{t}_{\text {statistik }}$ sebesar 5,062441, sedangkan pada jalur variabel keyakinan diri ke variabel penerimaan (SE$>$ ACC) nilai $t_{\text {statistik }}$ sebesar 5,938583, jalur berikutnya jalur variabel persepsi manfaat ke variabel penerimaan (PU->ACC) diperoleh nilai $t_{\text {statistik }}$ sebesar 4,536253 dan pada jalur terakhir jalur variabel pengalaman ke variabel penerimaan (PEU->ACC) didapatkan nilai $t_{\text {statistik }}$ sebesar 2,187516. Dengan demikian masing-masing variabel bebas (EX, SE, PU, PEU) secara parsial, signifikan mempengaruhi 
variabel terikat (ACC). Selanjutnya evaluasi goodness of fit melalui koefisien determinasi konstruk endogen [24]. Hasil analisis data menunjukan hipotesis diterima yang dimana pada variabel pengalaman, keyakinan diri, persepsi manfaat dan persepsi kemudahan menunjukan tiap variabel berpengaruh pada penerimaan SINJAB.

Berdasarkan hasil temuan menunjukkan bahwa pengalaman berpengaruh signifikan terhadap penerimaan SINJAB, dengan hasil $t_{\text {statistik }} 5,06>1,96$ (alpha 5\%). Selain itu ini menunjukkan bahwa variabel pengalaman mempengaruhi penerimaan SINJAB, artinya semakin lama dan banyak pengalaman penggunaan sistem informasi maka semakin tinggi penerimaan pada SINJAB. Variabel berikSutnya keyakinan diri diketahui berpengaruh signifikan pada penerimaan SINJAB, dengan nilai $\mathrm{t}_{\text {statistik }} 5,93>1,96$. Sehingga menunjukkan bahwa variabel keyakinan diri mempengaruhi penerimaan SINJAB Pemerintah Kota Payakumbuh, artinya semakin tinggi keyakinan diri dari pengguna SINJAB maka akan semakin tinggi penerimaan terhadap penggunaan SINJAB.

Selanjutnya variabel persepsi manfaat juga berpengaruh signifikan terhadap penerimaan SINJAB, hasil perhitungan $t_{\text {statistik }} 4,53>1,96$. Dengan demikian bahwa persepsi manfaat berpengaruh terhadap penerimaan SINJAB, artinya semakin dirasakan manfaat dari SINJAB maka akan semakin tinggi penerimaan terhadap SINJAB Pemerintah Kota Payakumbuh. Pada konsep TAM menunjukan persepsi manfaat dipengaruhi oleh persepsi kemudaha [25]. Pada variabel Persepsi Kemudahan Penggunaan pun pengaruh signifikan pada penerimaan SINJAB. Hasil perhitungan diperoleh $\mathrm{t}_{\text {statistik }} 2,18>1,96$. Diartikan bahwa variabel persepsi kemudahan berpengaruh pada penerimaan SINJAB, artinya semakin mudah penggunaan simdiklat memberikan dampak baik pada penerimaan. Hasil itu sejalan dengan [26] [27] mengenai self efficacy positif terhadap persepsi kemudahan penggunaan.

\section{KESIMPULAN}

Kesimpulan dari penelitian ini diperoleh pada variabel pengalaman, keyakinan diri, persepsi manfaat, dan persepsi kemudahan pengguna berpengaruh pada penerimaan SINJAB Pemerintah Kota Payakumbuh, sehingga disarankan Pemerintah Kota Payakumbuh dan melakukan pengembang SINJAB memperhatikan variabel-variabel tersebut untuk mendukung penerimaan SINJAB oleh operator SKPD, seperti peningkatan pengalaman operator dengan pelatihan, pendampingan berkala guna meningkatkan keyakinan diri, sosialisasi rutin tentang manfaat SINJAB dan panduan lengkap untuk kemudahan penggunaan.

\section{REFERENSI}

[1] Sudaryana, "Pengukuran Tingkat Kebergunaan Aplikasi Indonesia National Single Window (INSW) Menggunakan Technology Acceptance Model (Tam) Dan Stuctural Equation Modelling (SEM) Studi Kasus Balai Karantina Ikan," in Prosiding Seminar Nasional Manajemen Teknologi XII Program Studi MMT-ITS, 2010.

[2] "Republik Indonesia. Peraturan Menteri Dalam Negeri Nomor 12 Tahun 2008 tentang Pedoman Analisis Beban Kerja di Lingkungan Dalam Negeri dan Pemerintah Daerah.," 2008.

[3] J. Y. Mambu, G. Jonathan, G. M. Rumawouw, and A. T. Liem, "Analisis Kemanfaatan dan Kemudahan Sistem Informasi Unklab (SIU) menggunakan Technology Acceptance Model (TAM)," Creat. Inf. Technol. J., vol. 5, no. 2, p. 95, 2019, doi: 10.24076/citec.2018v5i2.175.

[4] F. D. Davis, "Perceived usefulness, perceived ease of use, and user acceptance of information technology," MIS Q. Manag. Inf. Syst., vol. 13, no. 3, pp. 319-339, 1989, doi: $10.2307 / 249008$.

[5] dan K. Mulyani, "Analisis Penerimaan Teknologi Student Information Terminal (S-IT) Dengan Menggunakan Technology Acceptance Model (TAM)," J. Wawasan Ilm., vol. 7, p. 12, 2015.

[6] Is.theorizeit.org, "Task-technology fit - IS Theory.," https://is.theorizeit.org/wiki/Task technology_fit., 2018 . .

[7] L. Tombilayuk and R. Jumardi, "Sistem Informasi Perpustakaan Menggunakan Model Task," vol. 1, pp. 68-73, 2018.

[8] W. Doll dan G. Torkzadeh, "The Measurement of End-User Computing," Satisf. MIS Quart, vol. 2, no. 12, pp. 259-274, 1998. 
[9] P. Metode, S. Dan, M. Eucs, and P. Oktavia, "Layanan Teknologi Informasi Pengguna Jasa Internet Service Provider ( Studi Kasus Pada PT . Platinum Citra Indonesia , Tangerang )," vol. 1, no. 2, pp. 69-79, 2012.

[10] A. Puji, F. Agushybana, and S. Patria, "Pengukuran Penerimaan Sistem Informasi EWSKIA Berdasarkan Persepsi Pengguna dengan Menggunakan Technology Acceptance Model," vol. 02, pp. 166-173, 2018.

[11] L. Liu, "The Technology Acceptance Model : A Meta-Analysis of Empirical Findings," no. January, 2005, doi: 10.4018/9781591404743.ch006.ch000.

[12] H. Van der Heijden, "Using the technology acceptance model to predict website usage Extensions and Empirical Test," Ser. Res. Memo., 2000.

[13] I. Ajzen, "Belief, attitude , intention and behaviour : An introduction to theory and research," no. July, 2015.

[14] Jogiyanto, Sistem Informasi Keprilakuan. Yogyakarta: Andi Offset, 2007.

[15] Rahadi, "Peranan Teknologi Informasi Dalam Peningkatan Pelayanan di Sektor Publik," in Seminar Nasional Teknologi, 2007.

[16] Igbaria,M., \& Ilvari, J, "The Effects of Self-efficacy on Computer Usage," Omega, Int.J.Mgmt Sci, vol. 23, pp. 587-605.

[17] A. Bandura, Self Efficacy: The Exercise of Control. New York: Freeman, 1997.

[18] S. Alharbi, Saleh \& Drew, "The Role of Self-efficacy in Technology Acceptance," vol. 1, 2019, doi: 10.1007/978-3-030-02686-8_85.

[19] G. Fogarty, "Ease Of Use In The Technology Acceptance Model :," pp. 122-129, 2000.

[20] Sugiyono, Statistika Untuk Penelitian. Bandung: Alfabeta, 2010.

[21] G. H. L. dan Imam, Partial Least Squares: Konsep, Teknik dan Aplikasi Menggunakan Program SmartPLS 2.0 M3. Semarang: Badan Penerbit Universitas Diponegoro, 2012.

[22] O. R. L. Sheng, "Adoption of Telemedicine Technology by Health Care Organizations : An Exploratory Study," no. September 2002, 2014, doi: 10.1207/S15327744JOCE1203.

[23] D. Turner, M., Kitchenham, B., Brereton, P., Charters, S., \& Budgen, "Does the technology acceptance model predict actual use?," A Syst. Lit. Rev. Inf. Softw. Technol., vol. 52, no. 5, pp. 463-479, 2010.

[24] I. Ghozali., Aplikasi Analisis Multivariat dengan Program SPSS. Semarang: Badan Penerbit Universitas Diponegoro, 2005.

[25] Supriyanti, dan Muhammad Cholil. 2016. Aplikasi Technology Acceptance Model Pada Sistem Informasi Manajemen Rumah Sakit di Rumah Sakit Soeharso Surakarta. Daya Saing Jurnal Ekonomi Manajemen Sumber Daya Vol. 18, No. 1, Juni 2016."

[26] N. Jalinus and H. P. Rosmena, "Understanding Behavioral Intention in Implementation of the ICTs Based on UTAUT Model," vol. 10, no. 2, pp. 96-107, 2019.

[27] J. Abramson, M. Dawson, and J. Stevens, "An Examination of the Prior Use of E-Learning Within an Extended Technology Acceptance Model and the Factors That Influence the Behavioral Intention of Users to Use M-Learning,” 2015, doi: 10.1177/2158244015621114. 